\title{
PENYULUHAN KESEHATAN MELALUI MEDIA CETAK BERPENGARUH TERHADAP PERAWATAN HIPERTENSI PADA USIA DEWASA DI KOTA DEPOK
}

\author{
Sri Haryani ${ }^{1 *}$, Junaiti Sahar ${ }^{2}$, Sukihananto $^{2}$ \\ 1. Poltekkes Kementerian Kesehatan Bengkulu, Bengkulu 38115, Indonesia \\ 2. Fakultas Ilmu Keperawatan Universitas Indonesia, Depok 16424, Indonesia \\ *E-mail: sri.ani73@yahoo.co.id
}

\begin{abstract}
Abstrak
Penyuluhan kesehatan merupakan cara yang digunakan untuk menyampaikan informasi kesehatan. Penyuluhan dapat dilakukan langsung melalui metode tatap muka atau dengan menggunakan media massa sebagai sarana dalam penyampaian informasi. Pada kenyataannya belum diketahui cara mana yang paling efektif dalam penyuluhan kesehatan untuk perawatan hipertensi usia dewasa. Penelitian ini bertujuan untuk mengetahui pengaruh penyuluhan kesehatan langsung dan melalui media massa dengan perawatan hipertensi pada usia dewasa. Penelitian ini menggunakan desain cross sectional. Responden yang terlibat adalah 122 usia dewasa yang merupakan total populasi. Hasil penelitian menunjukkan bahwa penyuluhan kesehatan langsung dan melalui media massa berhubungan secara bermakna dengan perawatan hipertensi pada usia dewasa. Penyuluhan kesehatan melalui media cetak merupakan faktor dominan pada perawatan hipertensi. Penelitian ini merekomendasikan untuk dilakukannya penyuluhan kesehatan secara berkala melalui selebaran, majalah dan poster.
\end{abstract}

Kata kunci: media cetak, media elektronik, penyuluhan kesehatan langsung, perawatan hipertensi, usia dewasa

\section{Abstract}

The influence of Direct Health Education and Using Mass Media to Treatment of Hypertension at the Age of Adult. Health education is a means of conveying health information to public. Health education can be done through giving face-to-face information to the adult patients and also by using mass media as supporting facilities in forwarding the information. However, it is not yet identified which method of education is more beneficial for the treatment of hypertension in adult. This study aimed to determine the influence of direct and mass media health education to the hypertension treatment in adult. This study used cross sectional design involving the total population of 122 adults. The results of the study showed that direct and mass media health education were significantly associated with hypertension treatment in adult. Health education via printed media became a dominant factor in the treatment of hypertension. This research recommends that regular health education should be done by means of leaflets, magazines and posters.

Keywords: adult, electronic media, face-to-face, health education, hypertension, print media

\section{Pendahuluan}

Usia dewasa merupakan populasi rentan untuk terjadinya penyakit yang dipengaruhi oleh banyak hal antara lain faktor biologi, fisik dan gaya hidup. Faktor biologi seperti bertambahnya usia dan penambahan berat badan. Gaya hidup yang kurang sehat, seperti mengkonsumsi makanan tinggi natrium dan tinggi lemak, merokok dan minum minuman yang mengandung alkohol serta minum kopi dapat menyebabkan peningkatan tekanan darah atau hipertensi (Rehm, et al, 2010).

Hipertensi banyak dialami oleh individu usia di atas 45 tahun dan banyak terjadi pada perempuan dibandingkan laki-laki. Faktor lain penyebab terjadinya hipertensi yaitu tingginya kadar kolesterol dalam darah dan adanya faktor genetik. Individu yang obesitas mempunyai 
risiko yang lebih tinggi untuk mengalami penyakit hipertensi. Faktor pekerjaan yang melebihi 51 jam per minggu merupakan faktor penyebab terjadinya hipertensi karena stres pekerjaan akan berdampak pada kelelahan dan sulit tidur (Carretero \& Oparil, 2000). Taraf ekonomi yang baik memicu individu untuk melakukan pola hidup kurang sehat dan sering mengkonsumsi makanan yang cepat saji.

Peningkatan tekanan darah yang tidak terkontrol dapat menyebabkan penyakit ginjal, jantung dan stroke serta dapat berakhir pada kematian. Perawatan hipertensi dapat dilakukan dengan pemantauan tekanan darah secara rutin, diet rendah garam, rendah lemak, melakukan olahraga/ aktivitas secara teratur dan melakukan manajemen stres yang baik (Buritan 2000 dalam Irmak, Duzoz, \& Bozyer, 2011; Perry, 2002 dalam Irmak, et al., 2011).

Perubahan perilaku dan persepsi individu dapat dilakukan dengan penyuluhan kesehatan dengan menggukan pendekatan model Health Belief Model (HBM). Model HBM dipengaruhi oleh faktor modifikasi seperti usia, jenis kelamin, budaya, ras, psikologis, sosial ekonomi, teman, kelompok pendidikan dan pengetahuan yang ada pada individu. Persepsi individu dalam memandang penyakit dipengaruhi oleh tindakan yang dilakukan seperti adanya penyuluhan kesehatan melalui media massa, koran, majalah ceramah, nasehat dari orang terdekat, adanya kartu pengingat, faktor penyakit yang dialami oleh anggota keluarga juga dapat memengaruhi persepsi individu dalam memandang penyakitnya sebagai ancaman (Allender \& Spradley, 2010).

Penggunaan media dalam penyuluhan kesehatan langsung dan melalui media massa harus mempertimbangkan usia dan minat peserta. Media yang dapat digunakan dalam penyuluhan kesehatan dapat menggunakan media power point, flip chart, media audiovisual, koran, majalah, televisi, radio, dan media lainnya.
Data WHO tahun 2009-2010 di Amerika Serikat pada usia 18 tahun lebih terdapat $28,6 \%$ penderita hipertensi dan $13 \%$ menjadi penyebab kematian. Sementara di Indonesia tahun 2010 menjadi urutan ke delapan penyakit terbanyak yang berobat pada rawat jalan rumah sakit. Berdasarkan profil kesehatan Jawa Barat tahun 2007 penderita hipertensi sebesar 2,50\%. Penyakit hipertensi di Depok menjadi urutan pertama penyakit terbanyak dialami oleh masyarakat usia 5 sampai $>64$ tahun yaitu sebesar 28.532 penderita. Data puskesmas Cimanggis di sebuah kelurahan di Kota Depok menunjukkan sebanyak 122 orang yang mengalami hipertensi pada usia 20-59 tahun (Laporan Tahunan Puskesmas Cimanggis, 2012).

Informasi tentang perawatan hipertensi didapatkan usia dewasa melalui selebaran, poster, booklet dan leaflet, saat mahasiswa praktik dan di puskesmas saat melakukan kontrol tekanan darah. Melalui media radio dan televisi ada walaupun dengan porsi yang sedikit dan jam tayang yang tidak sesuai dengan jam usia dewasa dapat mendengarkan dan melihat penyuluhan perawatan hipertensi.

Wawancara yang dilakukan dengan para kader kesehatan di sebuah kelurahan di Kota Depok mengidentifikasi bahwa pendidikan kesehatan mengenai penyakit hipertensi jarang dilakukan di Posbindu. Penyuluhan kesehatan secara langsung dalam bentuk diskusi, demonstrasi, penyebaran leaflet, booklet, dan menggunakan lembar balik pernah dilakukan pada saat mahasiswa melakukan praktek klinik di daerah tersebut. Penyuluhan melalui media elekronik (radio dan televisi) ada namun porsi siaran terbatas.

Berdasarkan uraian yang telah dijabarkan di atas, penelitian ingin mengetahui hubungan penyuluhan kesehatan langsung dan melalui media massa dengan perawatan hipertensi pada usia dewasa di sebuah kelurahan di Kota Depok. 
Penelitian ini bertujuan untuk mengetahui hubungan penyuluhan kesehatan langsung dan melalui media massa dengan perawatan hipertensi pada usia dewasa di sebuah kelurahan di kota Depok dan mengetahui faktor paling dominan antara penyuluhan kesehatan langsung dan melalui media massa dengan perawatan hipertensi setelah dikontrol variabel konfonding.

\section{Metode}

Desain penelitian ini menggunakan pendekatan cross sectional, menggunakan total populasi sejumlah 122 usia dewasa dengan hipertensi. Kuesioner disebarkan untuk mengidentifikasi pengaruh kesehatan yang paling dominan. Pengolahan data menggunakan salah satu program statistik.

\section{Hasil}

Karakteristik usia dewasa berdasarkan usia, jenis kelamin, pendidikan, pekerjaan, pendapatan dan lama sakit dapat dilihat pada tabel di bawah ini.

Tabel 1 menunjukkan bahwa lebih dari separuh responden pada rentang usia dewasa awal $73,0 \%$, berjenis kelamin perempuan $75,4 \%$, berpendidikan rendah $53,3 \%$, tidak bekerja 66 , $4 \%$, berpendapatan rendah $67,2 \%$, dan menderita sakit yang lama 51,6\%. Tabel 2 menunjukkan proporsi perawatan hipertensi yang efektif sama banyak dengan perawatan yang tidak efektif.

Tabel 4 menunjukkan bahwa 58,9\% usia dewasa yang mendapatkan penyuluhan kesehatan melalui media elektronik secara efektif melakukan perawatan hipertensi yang efektif $(58,9 \%)$. Berdasarkan hasil uji statistik $\left(\chi^{2}\right)$ didapatkan nilai p 0,03 dengan nilai OR 2,5 (CI 95\%; 1,1-5,1); artinya ada hubungan yang bermakna antara penyuluhan kesehatan melalui media elektronik dengan perawatan hipertensi pada usia dewasa dimana usia dewasa yang mendapat penyuluhan kesehatan melalui media elektronik secara efektif mempunyai peluang tiga kali untuk melakukan perawatan hipertensi secara efektif.

Tabel 5 menunjukkan bahwa 66,1\% usia dewasa yang mendapatkan penyuluhan kesehatan melalui media cetak secara efektif melakukan perawatan hipertensi secara efektif. Hasil uji statistik $\left(\chi^{2}\right)$ didapatkan nilai $\mathrm{p} \quad 0,002$ dengan nilai OR 3,4 (CI 95\%; 1,6;7,1); artinya ada hubungan bermakna antara penyuluhan kesehatan melalui media cetak dengan perawatan hipertensi pada usia dewasa. Usia dewasa yang mendapatkan penyuluhan kesehatan melalui media cetak mempunyai peluang 3,4 kali untuk melakukan perawatan hipertensi secara efektif.

Tabel 6 menggambarkan bahwa variabel yang paling dominan terhadap perawatan hipertensi adalah penyuluhan kesehatan melalui media cetak dan penyuluhan kesehatan langsung.

Tabel 1. Karaktertistik Responden berdasarkan Usia, Jenis Kelamin, Pendidikan, Pekerjaan, Pendapatan dan Lama Sakit

\begin{tabular}{llcc}
\hline & Variabel & $\begin{array}{c}\text { Jumlah } \\
(\mathbf{n})\end{array}$ & $\begin{array}{c}\text { Persentase } \\
(\boldsymbol{\%})\end{array}$ \\
\hline Usia & Dewasa Awal & 33 & 27,0 \\
& Dewasa Akhir & 89 & 73,0 \\
Jenis & Perempuan & 92 & 75,4 \\
Kelamin & Laki-laki & 30 & 24,5 \\
Pendidikan & Rendah & & \\
& (Tdk Sekolah-SMP) & 65 & 53,3 \\
& Tinggi (SMA-PT) & 57 & 46,7 \\
Pekerjaan & Bekerja & 41 & 33,6 \\
& Tidak Bekerja & 81 & 66,4 \\
Pendapatan & Rendah & 82 & 67,2 \\
& (<2.042.000) & 40 & 32,8 \\
& Tinggi (>2.042.000) & & \\
Lama Sakit & Lama & 63 & 51,6 \\
& Singkat & 58 & 47,5 \\
& & & \\
\hline
\end{tabular}

Tabel 2. Efektifitas Perawatan Hipertensi pada Usia Dewasa

\begin{tabular}{lccc}
\hline \multicolumn{2}{c}{ Variabel } & $\begin{array}{c}\text { Jumlah } \\
(\mathbf{n})\end{array}$ & $\begin{array}{c}\text { Persentase } \\
(\boldsymbol{\%})\end{array}$ \\
\hline Perawatan & Efektif & 61 & 50,0 \\
Hipertensi & Kurang Efektif & 61 & 50,0 \\
\hline
\end{tabular}


Tabel 3. Hubungan Penyuluhan Kesehatan Langsung dengan Perawatan Hipertensi pada Usia Dewasa

\begin{tabular}{|c|c|c|c|c|c|c|c|c|}
\hline \multirow{3}{*}{$\begin{array}{l}\text { Penyuluhan Kesehatan } \\
\text { Langsung }\end{array}$} & \multicolumn{4}{|c|}{ Perawatan Hipertensi } & \multirow{2}{*}{\multicolumn{2}{|c|}{ Total }} & \multirow{3}{*}{$\begin{array}{c}\text { OR } \\
(95 \% \mathrm{CI})\end{array}$} & \multirow{3}{*}{$\mathbf{p}$} \\
\hline & \multicolumn{2}{|c|}{ Efektif } & \multicolumn{2}{|c|}{ Kurang Efektif } & & & & \\
\hline & $\mathbf{n}$ & $\%$ & $\mathbf{n}$ & $\%$ & $\mathbf{n}$ & $\%$ & & \\
\hline Efektif & 40 & 69,1 & 18 & 31,0 & 58 & 100 & & \\
\hline Kurang Efektif & 21 & 32,8 & 43 & 67,2 & 64 & 100 & $4,550(2,1-2,7)$ & 0,000 \\
\hline Jumlah & 61 & 50,0 & 61 & 50,0 & 122 & 100 & & \\
\hline
\end{tabular}

Tabel 4. Hubungan Penyuluhan melalui Media Elektronik dengan Perawatan Hipertensi Usia Dewasa

\begin{tabular}{|c|c|c|c|c|c|c|c|c|}
\hline \multirow{3}{*}{$\begin{array}{c}\text { Penyuluhan Melalui Media } \\
\text { elektronik }\end{array}$} & \multicolumn{4}{|c|}{ Perawatan Hipertensi } & \multirow{2}{*}{\multicolumn{2}{|c|}{ Total }} & \multirow{3}{*}{$\begin{array}{c}\text { OR } \\
(95 \% \mathrm{CI})\end{array}$} & \multirow{3}{*}{$\mathbf{p}$} \\
\hline & \multicolumn{2}{|c|}{ Efektif } & \multicolumn{2}{|c|}{ Kurang Efektif } & & & & \\
\hline & $\mathbf{n}$ & $\%$ & $\mathbf{n}$ & $\%$ & $\mathbf{n}$ & $\%$ & & \\
\hline Efektif & 43 & 58,9 & 30 & 41,1 & 73 & 100 & & \\
\hline Kurang Efektif & 18 & 36,7 & 31 & 63,3 & 49 & 100 & $2,47(1,1-5,1)$ & 0,026 \\
\hline Jumlah & 61 & 50,0 & 61 & 50,0 & 122 & 100 & & \\
\hline
\end{tabular}

Tabel 5. Hubungan Penyuluhan Melalui Media Cetak dg Perawatan Hipertensi pada Usia Dewasa

\begin{tabular}{|c|c|c|c|c|c|c|c|c|}
\hline \multirow{3}{*}{$\begin{array}{c}\text { Penyuluhan Melalui Media } \\
\text { Cetak }\end{array}$} & \multicolumn{4}{|c|}{ Perawatan Hipertensi } & \multirow{2}{*}{\multicolumn{2}{|c|}{ Total }} & \multirow{3}{*}{$\begin{array}{c}\text { OR } \\
(95 \% \mathrm{CI})\end{array}$} & \multirow{3}{*}{$\mathbf{p}$} \\
\hline & \multicolumn{2}{|c|}{ Efektif } & \multicolumn{2}{|c|}{ Kurang Efektif } & & & & \\
\hline & $\mathbf{n}$ & $\%$ & $\mathbf{n}$ & $\%$ & $\mathbf{n}$ & $\%$ & & \\
\hline Efektif & 37 & 66,1 & 19 & 33,9 & 66 & 100 & & \\
\hline Kurang Efektif & 24 & 36,4 & 42 & 63,6 & 56 & 100 & $3,41(1,6-7,1)$ & 0,002 \\
\hline Jumlah & 37 & 66,1 & 19 & 33,9 & 66 & 100 & & \\
\hline
\end{tabular}

Tabel 6. Pemodelan Multivariat antara Penyuluhan Kesehatan Langsung dan Melalui Media Cetak dengan Perawatan Hipertensi Usia Dewasa

\begin{tabular}{|c|c|c|c|c|c|}
\hline \multirow{2}{*}{ Variabel Independen } & \multirow{2}{*}{ B } & \multirow{2}{*}{$\mathbf{p}$} & \multirow{2}{*}{ OR } & \multicolumn{2}{|c|}{ 95\% CI for $\operatorname{EXP}(B)$} \\
\hline & & & & Lower & Upper \\
\hline Penyuluhan Kesehatan Langsung & 1,11 & $0,01^{*}$ & 3,05 & 1,38 & 6,78 \\
\hline Melalui Media Elektronik & 0,66 & 0,11 & 1,93 & 0,86 & 4,31 \\
\hline Melalui Media Cetak & 1,28 & $0,00^{*}$ & 3,58 & 1,60 & 8,02 \\
\hline Constant & $-1,54$ & 0,00 & 0,22 & & \\
\hline
\end{tabular}

*Bermakna pada $\alpha=0,05$

\section{Pembahasan}

Hubungan Penyuluhan Kesehatan Lang-
sung dengan Perawatan Hipertensi pada Usia Dewasa. Hasil penelitian menunjukkan bahwa ada hubungan yang signifikan antara penyuluhan kesehatan langsung dengan perawatan hipertensi pada usia dewasa dengan nilai $\mathrm{p}=0,00$. Usia dewasa hipertensi yang mendapatkan penyuluhan kesehatan langsung secara efektif mempunyai kemungkinan 4,6 kali melakukan perawatan hipertensi secara efektif dibandingkan usia dewasa yang men- dapatkan penyuluhan kesehatan langsung kurang efektif. Penelitian ini sesuai dengan penelitian Nurhidayat, Eram, dan Bambang (2012) yang menunjukkan bahwa pengetahuan berhubungan dengan penggunaan media power point. Djaafar (2002) menyatakan bahwa penyuluhan langsung dengan menggunakan folder dapat meningkatkan pengetahuan, sikap dan keterampilan.

Penelitian Kapti (2010) menunjukkan adanya peningkatan pengetahuan setelah diberikan penyuluhan kesehatan melalui media audiovisual sebanyak $19,5 \%$. Sejalan dengan penelitian 
Kumboyo (2011), media audiovisual dapat memberikan pengalaman langsung melalui keunikan yang ditampilkan dan lebih dapat mengembangkan ranah kognitif, afektif dan psikomotor. Penelitian lain mengenai penggunaan audiovisual oleh Zamri (2009) menunjukkan bahwa peserta dapat mengingat lebih lama materi yang diberikan, karena melalui media audiovisual dapat memberikan pengalaman langsung melalui keunikan yang ditampilkan dan lebih dapat mengembangkan ranah kognitif, afektif, dan psikomotor.

Menurut Andersen, Medaglia, dan Henriksen (2012), metode penyuluhan kesehatan langsung berupa diskusi, panel, curah pendapat, demonstrasi, simulasi, bermain peran dan lain sebagainya yang dilakukan langsung antara penyuluh dan peserta (face to face) baik satu arah maupun dua arah memiliki keuntungan bagi peserta karena dapat langsung menunjukkan ekspresi selama proses dan langsung dapat dilihat kemampuan keterampilan, serta dituntut keaktifan dari peserta. Pada penyuluhan langsung diperlukan media tambahan seperti handout atau media audiovisual untuk dapat membantu dalam proses pembelajaran.

Menurut Notoatmodjo (2003), bahwa seseorang dapat belajar melalui panca inderanya. Seseorang dapat memiliki informasi tentang penyuluhan kesehatan hipertensi dan melakukan perawatan dengan baik bila dapat menggunakan indera pendengarannya $11 \%$ dan yang tertinggi adalah bila seseorang dapat menggunakan indera pengelihatannya yaitu sebesar $83 \%$. Seseorang yang dapat mengingat hasil belajar dengan baik dan dapat menggunakan pancaindera lebih dari satu pancaindera melalui apa yang dilihat dan didengarnya sebesar $50 \%$.

Berdasarkan hasil analisis bahwa penyuluhan kesehatan langsung yang dilakukan oleh tenaga kesehatan dengan media yang menarik akan memengaruhi usia dewasa dalam melakukan perawatan hipertensi. Usia dewasa yang mengetahui tentang cara perawatan hipertensi yang efektif sebesar 50,0\% akan melakukan perawatan dengan baik untuk mencegah terjadinya peningkatan tekanan darah dan mencegah akibat lanjut dari penyakit hipertensi seperti stroke, jantung dan ginjal yang bisa menyerang siapa saja tanpa memandang jenis kelamin dan usia.

Hasil analisis univariat usia dewasa menunjukkan sebagian sebesar 91,0\% memiliki pengetahuan baik, sikap yang baik $45,1 \%$ dan memiliki keterampilan yang baik $42,6 \%$. Hal ini menunjukkan bahwa penyuluhan kesehatan langsung yang diberikan dengan efektif dan dilakukan secara rutin pada usia dewasa dengan hipertensi akan sangat membantu usia dewasa dalam melakukan perawatan hipertensi di rumah dalam bentuk pemantauan tekanan darah secara rutin, pengaturan diet, melakukan olahraga/aktifitas teratur dan manajemen stres yang baik.

\section{Hubungan Penyuluhan Kesehatan melalui Media Cetak dengan Perawatan Hipertensi Pada Usia Dewasa. Hasil penelitian menunjuk-} kan bahwa ada hubungan bermakna antara penyuluhan kesehatan melalui media cetak dengan perawatan hipertensi pada usia dewasa dengan $(p=0,002)$. Usia dewasa yang mendapatkan penyuluhan kesehatan melalui media cetak secara efektif mempunyai kemungkinan 3,4 kali melakukan perawatan hipertensi yang efektif dibandingkan dengan usia dewasa yang mendapatkan penyuluhan kesehatan melalui media cetak kurang efektif. Hadi, Sugiarto, Mula, dan Rahmah (2011) menyatakan bahwa adanya peningkatan kognitif, afektif dan psikomotor setelah diberikan penyuluhan kesehatan dengan menggunakan media komik.

Susanti (2011) menyatakan bahwa ada peningkatan pengetahuan yang signifikan setelah diberikan intervensi pendidikan kesehatan dengan meng-gunakan media cetak sebesar $81,46 \%$. Hal ini karena media cetak dapat menampilkan gam-bar dan bahasa yang mudah dimengerti oleh sasaran. Penelitian Wahyuni, Sarma, dan Pulungan (2007) 
menunjukkan hasil bahwa terdapat hubungan yang bermakna antara penyuluhan yang diberikan melalui media massa dengan perilaku $(\mathrm{p}=0,009)$.

Menurut Gupta dan Guptha (2010), media cetak berupa majalah dan surat kabar yang sudah digunakan sejak beberapa tahun silam dalam pemberian pendidikan kesehatan. Media surat kabar yang informatif dan menarik akan efektif digunakan dalam promosi kesehatan seperti promosi tentang nutrisi, gaya hidup, dan mempromosikan hasil penelitian yang lainnya.

Media majalah dan koran bersifat informatif, menarik, dan berlaku singkat sehingga perlu mempertimbangkan faktor pembiayaan dan dampaknya terhadap masyarakat. Menurut Susanti (2011) ada pengaruh signifikan $(p=$ 0,000 ) setelah dilakukan intervensi pendidikan kesehatan dengan menggunakan media leaflet dalam meningkatkan pengetahuan $81,46 \%$. Hal ini disebabkan media majalah dan koran berisi bahasa-bahasa yang informatif dan menarik serta dilengkapi dengan gambar.

Menurut Allender dan Spradley (2010), penyebaran informasi melalui media massa lebih efektif digunakan dalam penyuluhan kesehatan karena dapat menjangkau kelompok sasaran yang luas, seperti masyarakat dengan berpenghasilan rendah dan etnis yang beragam, serta kelompok resiko (penyakit menular) yang sulit untuk ditemui satu persatu. Penggunaan media poster sebagai media dalam promosi kesehatan dituntut pembuatnya memiliki ide yang komplek dan kreatif dalam menampilkan gambar sehingga lebih menarik untuk dibaca oleh audien, sedangkan media selebaran dapat menjangkau sasaran yang luas dalam kegiatan promosi kesehatan.

Menurut analisis peneliti bahwa penyuluhan kesehatan melalui media cetak perlu memperhatikan manfaat dan efektifitas penggunaannya bagi sasaran dan pemberi penyuluh, sebab media cetak yang kurang menarik akan kurang diperhatikan oleh pembaca dan juga membutuhkan biaya yang mahal dalam produksi. Berdasarkan hasil kuesioner bahwa hasil kuesioner penyuluhan kesehatan melalui media cetak kurang efektif $54,1 \%$ dibandingkan dengan yang efektif $45,9 \%$, ini karena media cetak yang telah diberikan oleh tenaga kesehatan dan mahasiswa praktik memiliki tampilan yang menarik dengan bahasa yang mudah dimengerti oleh masyarakat sehingga dapat dimengerti dan diterapkan dalam kehidupan sehari-hari dalam melakukan perawatan hipertensi.

\section{Kesimpulan}

Ada pengaruh bermakna penyuluhan kesehatan langsung dan melalui media massa dengan perawatan hipertensi pada usia dewasa di sebuah kelurahan di kota Depok dan penyuluhan kesehatan melalui media cetak merupakan faktor yang paling dominan berhubungan dengan perawatan hipertensi pada usia dewasa setelah dikontrol dengan variabel perancu.

Perlu mengalokasikan anggaran dana untuk dapat mencetak brosur, leaflet, poster, pamplet dan media cetak lainnya yang menarik dan perawat komunitas perlu menggunakan media cetak dalam memberikan penyuluhan kesehatan. Perlu dilakukannya penyuluhan kesehatan melalui media elektronik seperti TV dan radio yang disesuaikan dengan jadwal usia dewasa berada di rumah dan perlu dilakukannya penelitian lebih lanjut terkait perawatan hipertensi pada usia dewasa dengan metode yang berbeda misalnya menggunakan desain eksperimen atau metode kualitatif, serta kegiatan promosi kesehatan dapat dilakukan bersamaan dengan jadwal kegiatan yang ada di masyarakat (FA, AG, DW).

\section{Ucapan Terima Kasih}

Ucapan terima kasih diberikan kepada pemberi sumber dana yaitu Poltekkes Kemenkes Bengkulu. 


\section{Referensi}

Allender, J.A., \& Spradley, B.W. (2010). Community health nursing: Promoting and protecting the public's health (6th Ed). Philadelphia: Lippincott Williams \& Wilkins.

Andersen, K.N., Medaglia.R., \& Henriksen.H.Z. (2012). Social media in public health care: impact domain propositions. Government Information Quarterly. http://dx.doi.org/10.10 16/j.giq.2012.07.004.

Carretero, O.A., \& Oparil, S. (2000). Clinical cardiology: New frontiers. Circulation, 101,329-335. Diperoleh dari http://circ.ahajour nals.org/content/circulationaha/101/3/329.full. pdf.

Gupta, R., \& Guptha,S. (2010). Strategies for initial management of hypertension. Indian $J$ Med Res, 132(5), 531-542. Diperoleh dari https://www.ncbi.nlm.nih.gov/pmc/articles/PM C3028941/

Hadi, C., Sugiarto., Mula, K.Y., \& Rahmah, Z. (2011). Pengaruh penyuluhan kesehatan dengan media komik tanggap DBD terhadap peningkatan pengetahuan dan sikap tentang pencegahan DBD di SDN Banjarejo Ngadiluwih Kabupaten Kediri (Tesis, tidak dipublikasikan). Faculty of Medicine Brawijaya University Malang, Jawa Timur, Indonesia.

Irmak, Z., Duzoz, G., \& Bozyer, I., (2011). The effeectiveness of a follow-up program on blood pressure and cardiovascular risk factors for hypertensive patients. Australian Journal of Advanced Nursing, 28 (2), 60-66. Diperoleh dari http://search.informit.com.au/document Summary;dn=056564996163781;res=IELHEA

Kapti. (2010). Efektifitas audiovisual sebagai media penyuluhan kesehatan terhadap terhadap peningkatan pengetahuan dan sikap $i b u$ dalam tatalaksana balita dengan diare di dua rumah sakit Kota Malang (Tesis magister, tidak dipublikasikan). Program Studi Magister Fakultas Ilmu Keperawatan Universitas Indonesia, Depok - Jawa Barat, Indonesia.
Kumboyo. (2011). Perbedaan efek penyuluhan kesehatan menggunakan media cetak dengan media audio visual terhadap peningkatan pengetahuan pasien tuberkulosis. Jurnal Ilmiah Kesehatan Keperawatan, 7 (1), 9-12. Diperoleh dari http://ejournal.stikesmuh gombong.ac.id/index.php/JIKK/article/view/21

Notoatmodjo. (2003). Pendidikan dan perilaku kesehatan. PT. Rineka Cipta: Jakarta.

Nurhidayat, O., Eram, T.P., \& Bambang, W. (2012). Perbandingan media power point dengan flip chart dalam meningkatkan pengetahuan kesehatan gigi dan mulut (Tesis Magister, Universitas Negeri Semarang). Fakultas Ilmu Keolahragaan Universitas Negeri Semarang. Diperoleh dari http:// journal.unnes. ac.id.

Rehm, J., Baliunas, D., Borges, G. L., Graham, K., Irving, H., Kehoe, T., ... \& Roerecke, M. (2010). The relation between different dimensions of alcohol consumption and burden of disease: an overview. Addiction, 105(5), 817-843. doi: 10.1111/j.1360-0443.2010.028 99.x

Susanti, F. (2011). Efektifitas multimedia interaktif sebagai media pendidikan kesehatan terhadap peningkatan pengetahuan lanjut usia tentang pencegahan penyakit asam urat di Kelurahan Tugu Depok (Tesis, magister tidak dipublikasikan). Program Magister Keperawatan Fakultas Ilmu Keperawatan Universitas Indonesia, Depok - Jawa Barat, Indonesia

Wahyuni, E,S., Sarma, M. \& Pulungan, I. (2007). Faktor-faktor yang berhubungan dengan perilaku pembaca dalam memperoleh informasi gaya hidup sehat (studi kasus pembaca tabloid senior di Kecamatan Bogor Utara). Jurnal Penyuluhan, 3 (2), 100-109. Diperoleh dari http://journal.ipb.ac.id/ index.php/jupe/article/view/2157

Zamri, N.(2009). Pembelajaran sastra dengan menggunakan media audio visual di MTS. Depok: FIB Universitas Indonesia. 
-Laporan Tahunan Puskesmas

Cimanggis. (2012). 